\title{
Insect occurrence and losses due to phytophagous species in the amaranth Amaranthus hypocondriacus L. crop in Puebla, Mexico
}

\author{
Agustín Aragón García ${ }^{1}$, Miguel Ángel Damián Huato', Manuel Huerta Lara ${ }^{1}$, Francisco J. \\ Sáenz-de-Cabezón ${ }^{2}$, Ignacio Pérez-Moreno ${ }^{2}$, Vicente Marco-Mancebón ${ }^{2}$ and \\ Jesús F. López-Olguín ${ }^{1 *}$
}
${ }^{1}$ Departamento de Agroecología y Ambiente, Instituto de Ciencias, Benemérita Universidad Autónoma de Puebla, Av. 14 sur 6301, C. U., 72570-Puebla, México.
${ }^{2}$ Departamento de Agricultura y Alimentación, Unidad de Protección de Cultivos, Universidad de La Rioja, España. C/ Madre de Dios 51, 26006-Logroño, España.

Accepted 2 November, 2011

\begin{abstract}
A field survey for insects associated with amaranth Amaranthus hypocondriacus L. (Amaranthaceae) was conducted in the semiarid Region Mixteca of Puebla State in Mexico. Also, the losses to the crop caused by the phytophagous species were assessed. Samples were collected every fifteen days during one year in five plots to obtain a representation of the phytophagous and beneficial insects, and of the percentages of plants infested with the principal phytophagous insects. The species that were observed causing considerable damage to the crop were Hypolixus truncatulus Fab. (Coleoptera: Curculionidae), Spodoptera exigua (Hübner) (Lepidoptera: Noctuidae), Pholisora catullus (Fab.) (Lepidoptera: Hesperiidae) and Phyllophaga ilhuicaminai Morón (Coleoptera: Melolonthidae). Borers infested $92 \%$ of the crop, while the white grubs group $45 \%$. Yield losses by general insects without pest control program were $65.5 \%$. Foliage and soil insects reduced the yield to 44.2 and $39.1 \%$, respectively. This is the first report of quantification of losses due to pest insects in the amaranth crop.
\end{abstract}

Key words: Amaranthaceae, alternative crops, associated insects, determination of species, phytophagous insects, quantification of losses.

\section{INTRODUCTION}

Several species of the genus Amaranthus (Amaranthaceae) are recognized in Asia, Mesoamerica, and South America as a food crop that can be used as a vegetable or as a seed grain. Moreover, its cultivation has been extended to the United States of America, Caribbean islands, Europe and Africa (Becket et al., 1992; Clarke-Harris and Fleischer, 2003; Gimplinger et al., 2008). Amaranth can be cultivated in arid zones where other commercial crops cannot be grown; the seeds, besides their well-known nutritive characteristics,

\footnotetext{
${ }^{{ }}$Corresponding author. E- mail: jesus.lopez@correo.buap.mx or olguin33@hotmail.com. Tel/Fax: +52-222-229-5500 Ext. 7357, 7348.
}

could be a source of phenolic compounds of high antioxidant properties (Barba de la Rosa et al., 2009). The amaranth grain provides an ideal amino acid composition for human nutrition. Moreover, the high content of Lysine, Arginine and Histidine makes amaranth seeds a good dietary supplement for treating child malnutrition (Gimplinger et al., 2008). The grains of amaranth could be considered either as cereals or legume, due to the fact that they contain more than $15 \%$ protein in dry base, which is complemented with the sulphurous amino acids and the lysine they contain (Downton, 1973; Becket et al., 1992; Gorinstein et al., 1999).

Historically, the seeds of amaranth Amaranthus hypocondriacus $L$. played a very important part in the diet 
of Mesoamerican cultures (López-Munguía et al., 1994). In the Mexican prehispanic period, amaranth was one of the most important crops for the Aztecs, who produced approximately 20 thousand tons annually (Trinidad et al., 1990). Later, the Spanish conquerors prohibited its cultivation, because the indigenous Mexicans used it as an offering to their gods in their religious ceremonies. In the XVI century, it was cultivated from the west of the country (Jalisco) to the east (Oaxaca), but despite its importance and the resistance of the indigenous people, its cultivation was reduced drastically during the XVII and XVIII centuries. Its production nearly disappeared and was reduced to small agricultural areas. In the sixties there were few states dedicated to the production of amaranth; however, in recent times its production has increased considerably.

With the increase in amaranth production, more studies have been conducted in order to evaluate the insect complex associated with this crop. In the 1980s, some isolated reports were carried out regarding insect species that were found to cause damage to the crop. Espitia (1990) mentioned five species of insects that cause important damage to amaranth in the Central Plateau of México: Lixus truncatulus Fab. (Coleoptera: Curculionidae), Disonycha melanocephala Jacoby (Coleoptera: Chrysomelidae), Lygus lineolaris P. de Beauvois (Hemiptera: Miridae), the "green worm" (Lepidoptera, unidentified) and a "black aphid" (Homoptera: Aphididae, unidentified).

Later, Aragón et al. (1997) in a study located in the Valley of Tehuacán, Puebla, noticed that the species that cause damage to the amaranth crop could be classified into three groups: the stem borers, the leaf eaters and the root pests. Among them the most important species belonging to the borer complex were: $L$. truncatulus (Coleoptera: Curculionidae) and Amauromyza abnormalis Malloch (Diptera: Agromyzidae); the insects that damage the foliage and the panicle (leaf eaters) were Spodoptera exigua (Hübner) (Lepidoptera: Noctuidae), Pholisora catullus (Lepidoptera: Hesperiidae), the "grasshopper" Sphenarium sp. (Orthoptera: Acrididae), the "aphid" Macrosiphum sp. (Hemiptera: Aphidae), the "jumping flea" D. melanocephala (Coleoptera: Chrysomelidae) and the ant Atta mexicana (Smith); and the "white grub" Phyllophaga cuicateca Morón and Aragón (Coleoptera: Melolonthidae), which damages the root system. TorresSaldaña et al. (2004) reported the presence of Hypolixus truncatulus (Fab.) (Coleoptera: Curculionidae) and $A$. abnormalis causing damage to the stems of $A$. hypochondriacus in Tulyehualco, Federal District, Mexico.

Although there is now a list of the insect complex associated with the crop in Mexico, the losses caused by them are unknown. Therefore, the aim of this study was to construct and update the list of insects associated with amaranth, as well as to estimate the yield and economical losses caused by each group of pests proposed by
Aragon et al. (1997) for this important crop.

\section{MATERIALS AND METHODS}

For the diagnostic investigation in the Region Mixteca in Puebla State, and during the 2008 and 2009 agricultural cycles, five plots were selected, in which amaranth was transplanted according to the regional agricultural practices for this crop, which consisted in tilling, harrowing, plowing, transplanting, applying organic fertilizer, first hoeing, second hoeing and threshing or harvesting. No insecticides or fungicides were applied in the plots under study. These plots were located in the Mixteca Region in Puebla, Mexico

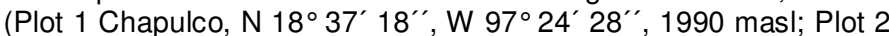
Altepexi, N $18^{\circ} 21^{\prime} 45^{\prime \prime}$, W $97^{\circ} 17^{\prime} 13^{\prime \prime}, 2220$ masl; Plot 3 Santa Maria la Alta, N $18^{\circ} 36^{\prime} 13^{\prime \prime}$, W 97 $39^{\prime} 43^{\prime \prime}$, 1951 masl; Plot 4 San Pedro Atzumba, N $18^{\circ} 08^{\prime} 24^{\prime \prime}$, W $97^{\circ} 35^{\prime} 34^{\prime \prime}, 1929$ masl; Plot 5 San Gabriel Chilac, N $18^{\circ} 18^{\prime} 59^{\prime \prime}$, W $97^{\circ} 21^{\prime} 40^{\prime \prime}, 1263$ masl). The climates of this region present a gradation from warm humid of the eastern slopes of the Sierra Negra of Puebla, to the warm and dry climate of the valley of Tehuacán; in the most elevated parts of the region of Zapotitlán Salinas (higher than $1600 \mathrm{~m}$ altitude), the climate becomes temperate with mean annual temperatures that vary from 12 to $18^{\circ} \mathrm{C}$, with rainfall that varies from 200 to $1500 \mathrm{~mm}$, approaching the west the precipitation decreases to $600 \mathrm{~mm}$; towards the Valley of Tehuacán, the climate is dry warm with annual rainfall of less than $500 \mathrm{~mm}$ and a mean temperature of $20^{\circ} \mathrm{C}$.

The plots were located in the lands of cooperating producers, and their size varied from 550 to $\quad 860 \mathrm{~m}^{2}$, according to the surface that each producer assigned to the crop. For each plot a field diagram was made, in which the bundles of amaranth were located, each bundle with a number of amaranth plants between two and four.

After the date of transplanting (June) and until harvest (November), samplings were made every 15 days in each one of the plots. The samplings were carried out in 20 randomly selected plants of each plot, locating them in the corresponding field diagram, and in each sampling different bundles were selected. In each selected bundle, the insects present on each plant were collected with the help of an entomological aspirator, which were deposited in polyethylene bags labelled with the following information: collection date, number of bundle and location of collection; in addition, the part of the plant of which the insects were found was recorded.

The flying insects were collected using a sweeping net. Fifty sweeps with a sweep net were conducted on the plants inside each plot, leaving ten meters on each side to reduce the risk of capture non-amaranth insects. Sampling of root feeders were made by removing all of the area near the root, with a volume of $30 \times 30 \times$ $30 \mathrm{~cm}$. The insects present were collected and deposited in Petri dishes with soil and part of the root in order to obtain adults. To obtain insect borers, plant stems with signs of boring damage were opened in situ. The plants with insect immature stages were transported in pots to cages of white cloth, which were stored in the Entomology Laboratory in order to allow continuation of their development until the adults' stage was reached.

Immature leaf eating stages were grown in captivity providing them leaves of amaranth as food and also with a modified artificial diet proposed by Minm (1984) for the corn borer Spodoptera frugiperda Smith (Burton and Perkins, 1989). The collected insects were identified by different specialists of the Colegio de Postgraduados of Montecillos, State of México, and of the Instituto de Ecología A.C., Xalapa, Veracruz, México. All collected specimens were deposited at the Entomological Collection of the Instituto de Ciencias of the Benemérita Universidad Autónoma de Puebla. 
To estimate the losses caused by amaranth pests, an experiment was conducted in 2008 from June to November, covering all of the plant cycle. The plot in which the experiment was established was selected based on its agroecological representativity with respect to the agricultural conditions in the zone. The treatments established were: 1 . Total control of pests in the root and foliage; 2 . Control of pests that damage the root; 3 . Control of foliage pests; and 4. Control (without pest control). The control of pests that damage roots was carried out by applying granulated Furadan ${ }^{\circledR} 5 \mathrm{G}$ (carbofuran insecticide) in doses of $25 \mathrm{~kg} \mathrm{ha}^{-1}$ at the moment of transplanting and the control of foliage pests was carried out 10 days after transplanting, applying $1.0 \mathrm{~kg} \mathrm{ha}^{-1}$ of Sevin ${ }^{\circledR} 80$ WP (carbaryl insecticide) and afterwards every 15 days, during the entire development of the plant.

The effect of the treatments was evaluated by using a complete randomized blocks design with four replicates, obtaining a total of 16 experimental units. Each experimental unit consisted of an area of $56 \mathrm{~m}^{2}$, in which 56 bundles of plants of amaranth were transplanted; each bundle with four plants of $10 \mathrm{~cm}$ height and one meter between bunches. The data were obtained from the 12 central bundles, the experimental units were two meters apart from each other and the total size of the experimental plot was $1440 \mathrm{~m}^{2}$.

The agricultural tasks carried out prior to transplanting the amaranth were as follows: tilling, harrowing and furrowing, then transplanting was made and at 10 days thinning was done, leaving three plants per bunch. The agricultural tasks that followed were applying organic fertilizer, first hoeing, weeding, harvesting, and drying and cleaning of the seed. Worm compost was applied as fertilizer in doses of $200 \mathrm{~g}$ per bunch. All of the agricultural tasks were carried out homogeneously for all of the experimental units.

The parameter evaluated was the production of amaranth grain per useful plot, which was extrapolated to kilograms per hectare. To determine if there was any difference among the effect of the treatments, data were subjected to an analysis of variance, followed by the Tukey multiple range test $(\alpha=0.05)$. Losses caused by the phytophagous insect complex were obtained by calculating the difference between the means of grain production in plots under total pest control minus plots without pest control. Losses due to phytophagous insects were adjusted to the production that would be obtained in the absence of damage by insects (mean of grain production in plots under total pest control). The losses caused by root and foliage pests were calculated in $\mathrm{kg} \mathrm{ha}^{-1}$ and percentage.

Yield loss value was determined considering the price of amaranth at the moment of harvest. At the same time, the cost of the chemical control of pests in each treatment was obtained. The economic relevance of each insect pest was determined by comparing the amount of loss per insect. The cost of the chemical pest control, referred to one hectare, was calculated based on the cost of product used (Carbofuran or Carbaryl insecticide) plus the labour cost.

\section{RESULTS}

During the research 3,414 insect specimens were collected. Among them, 49 genera and 52 species were identified. Those specimens were grouped into seven orders and 29 families (Table 1). The damaging species can be classified into three large groups: the stem borers, the leaf eaters and the root pests. The stem borers group is among the most important pests, and is apparently comprised of at least five species, of which it has been possible to identify the four most abundant, two of them to the species level, $A$. abnormalis, $H$. truncatulus; and the others to the genus level, Trichobaris sp. and
Pantomorus sp. (Coleoptera: Curculionidae). The infestations caused by this complex reached up to $92 \%$, focusing the damage at the base of the stem near the root, in the stems and in the panicle; the damages appear in the form of galleries.

Among the insects that damage the foliage and the panicle, we found the beet armyworm $S$. exigua infested $64 \%$ of the plants and $P$. catullus infested $57 \%$. We also found: the "grasshopper" Sphenarium purpurascens Charp. (Orthoptera: Acrididae); the "aphid" Macrosiphum $\mathrm{sp}$.; the "jumping flea" $D$. melanocephala, Herpetogramma bipunctalis (Fab.) (Lepidoptera: Pyralidae), Epicauta sp. (Coleoptera: Meloidae), and Piesma cinerea Say. (Hemiptera: Piesmatidae). In the foliage, the presence of the ant $A$. mexicana was also detected, as well as the ants Pogonomyrmex barbatus (Smith) (Hymenoptera: Formicidae) and Solenopsis geminata (Fab.) (Hymenoptera: Formicidae), which were observed carrying amaranth seeds.

The damages in the root system are attributed above all to the "white grubs" group with an infestation of $45 \%$ of the plants. The most abundant species were $P$. cuicateca, Phyllophaga ravida (Blanchard), Phyllophaga obsoleta (Blanchard) and Phyllophaga ilhuicaminai (Coleoptera: Melolonthidae), although there are also at least three other species of white grubs of the genera Phyllophaga, Anomala and Diplotaxis. Collected insects considered beneficial to pest control, due to the fact that they have been reported as generalist or non specialized predators or parasitoids, we found: the "ladybug" Hippodamia convergens (Guérin-Méneville) (Coleoptera: Coccinellidae), a tachinid fly belonging to the genus Voria (Diptera: Tachinidae) and several species of Chrysopa (Neuroptera: Chrysopidae). The months in which the largest number of natural enemies was collected were September and October.

With respect to the results of the experiment for the estimation of losses, the ANOVA showed significant effect of the treatments $(F=30.02 ; d f=3,9 ; p=0.0001)$ on grain production. Through the Tukey test $(\alpha=0.05)$, it resulted that the mean of production of the total control of pests was significantly different from the means of the treatments consisting of control of soil pests and foliage pests $(H S D=211.89 \mathrm{~kg})$; these two had means with no significant statistical difference. On the other hand, the means of the three treatments where pest control measures were applied were significantly different from the control treatment (without pest control) (Table 2).

The three pests groups together caused a loss of 657.1 $\mathrm{kg} \mathrm{ha}^{-1}$, equivalent to $65.5 \%$ of the yield, while the foliage and soil pests reduced yield by 44.2 and $39.1 \%$, respectively (Table 2 ).

\section{DISCUSSION}

The number of species collected shows the wide diversity of insects associated with the amaranth crop for the zone 
Table 1. List of insect species found in the amaranth crop during the agricultural cycles 2008-2009 in the Region Mixteca in Puebla, México.

\begin{tabular}{|c|c|c|c|c|}
\hline Order & Family & Scientific name & Common name $^{\&}$ & Abundance* $^{*}$ \\
\hline Orthoptera & Pyrgomorphidae & Sphenarium 78'purpurascens Charpentier & Grasshopper & 14 \\
\hline \multirow[t]{10}{*}{ Hemiptera } & Aphididae & Macrosiphum sp. & Aphid & $>1000$ \\
\hline & Cicadellidae & Empoasca sp. & Leafhopper & 5 \\
\hline & Piesmatidae & Piesma cinerea Say & Ash-gray leaf bug & 2 \\
\hline & Pyrrhocoridae & Dysdercus sp. & Mimic cotton stainer & $<1$ \\
\hline & \multirow[t]{4}{*}{ Pentatomidae } & Euschistus biformis Stal & Stink bug & $<1$ \\
\hline & & Mormidea sp. & Fragrant bug & $<1$ \\
\hline & & Podisus aculissimus Stal & Spined soldier bug & $<1$ \\
\hline & & Nezara viridula (Linnaeus) & Southern green stink bug & $<1$ \\
\hline & Miridae & Lygus lineolaris (Palisot de Beauvois) & Tarnished plant bug & 15 \\
\hline & Rhopalidae & Aufeius sp. & Stink bug & $<1$ \\
\hline Neuroptera & Chrysopidae & Chrysopa sp. & Chrisopa, Goldeneyed lacewing & $<1$ \\
\hline \multirow[t]{27}{*}{ Coleoptera } & Carabidae & Lebia bivittata Fabricius & Ground beetle & $<1$ \\
\hline & \multirow[t]{4}{*}{ Chrysomelidae } & Disonycha melanocephala Jacoby & Amaranth bulging flea beetle, Jumping flea & 2 \\
\hline & & Diphaulaca bicolor De Geer & Flea beetle & $<1$ \\
\hline & & Diabrotica balteata LeConte & Banded cucumber beetle & $<1$ \\
\hline & & Zygogramma signatipennis (Stal) & Leaf beetle & $<1$ \\
\hline & \multirow[t]{2}{*}{ Coccinellidae } & Hippodamia convergens Guérin-Méneville & Lady bug & 2 \\
\hline & & Cycloneda sp. & Lady beetle & $<1$ \\
\hline & \multirow[t]{4}{*}{ Curculionidae } & Hypolixus truncatulus Fabricius & Stem weevil & 2 \\
\hline & & Trichobaris sp. & Stalk borer & $<1$ \\
\hline & & Baris sp. & Root weevil & $<1$ \\
\hline & & Pantomorus sp. & Palestriped flea beetle & $<1$ \\
\hline & \multirow[t]{9}{*}{ Melolonthidae } & Phyllophaga cuicateca Morón \& Aragón & White grub & 2 \\
\hline & & Phyllophaga ravida (Blanchard) & White grub & 4 \\
\hline & & Phyllophaga obsoleta (Blanchard) & White grub & 4 \\
\hline & & Phyllophaga ilhuicaminai Morón & White grub & 6 \\
\hline & & Cyclocephala lunulata Burmeister & Masked chafer & 1 \\
\hline & & Macrodactylus ocreatus Bates & Mexican chafer & 5 \\
\hline & & Diplotaxis angularis LeConte & Little beetle & 2 \\
\hline & & Cotinis mutabilis (Gory \& Percheron) & Green fruit beetle & $<1$ \\
\hline & & Euphoria subtomentosa Mannerheim & Flower beetle & $<1$ \\
\hline & Elateridae & Aeolus sp. & Wireworm & $<1$ \\
\hline & \multirow[t]{2}{*}{ Tenebrionidae } & Bothrotes inaequalis (LeConte) & Darkling beetle & $<1$ \\
\hline & & Nautes sp. & Darkling beetle & $<1$ \\
\hline & Meloidae & Epicauta sp. & Blister beetle & 2 \\
\hline & Cleridae & Enoclerus bombycinus (Chevrolat) & Clerid beetle & $<1$ \\
\hline & Buprestidae & Acmaeodera sp. & Buprestid beetle & $<1$ \\
\hline & Melyridae & Collops quadrimaculatus (Fabricius) & Flower beetle & $<1$ \\
\hline \multirow[t]{2}{*}{ Lepidoptera } & Hesperiidae & Pholisora catullus (Fabricius) & Common sootywing leaf eating & 1 \\
\hline & Noctuidae & Spodoptera exigua (Hübner) & Beet armyworm & 12 \\
\hline
\end{tabular}


Table 1. Contd.

\begin{tabular}{|c|c|c|c|c|}
\hline & Pyralidae & Herpetogramma bipunctalis (Fabricius) & Southern beet webworm & 3 \\
\hline & & Spoladea recurvalis (Fabricius) & Hawaiian beet webworm & $<1$ \\
\hline Hymenoptera & Formicidae & Atta mexicana (Smith) & Mexican leafcutting ant & $<1$ \\
\hline & & Pogonomyrmex barbatus (Smith) & Red harvester ant & $<1$ \\
\hline & & Solenopsis geminata (Fabricius) & Tropical fire ant & $<1$ \\
\hline & Braconidae & Bracon sp. & Wasp & $<1$ \\
\hline & Vespidae & Polister sp. & Paper wasp & $<1$ \\
\hline & & Polybia sp. & Leaf wasp & $<1$ \\
\hline Diptera & Agromyzidae & Amauromyza abnormalis (Malloch) & Amaranth stem borer & 5 \\
\hline & Tachinidae & Voria ruralis (Fallen) & Tachinid fly & $<1$ \\
\hline & Otitidae & Otitidae sp. & Stalk borer & $<1$ \\
\hline
\end{tabular}

\footnotetext{
${ }^{\&}$ Committee on the common names of insects. Entomological Society of America. 2011. * Average individuals per plant.
}

Table 2. Means of production of amaranth grain under different treatments and analysis of losses due to pests of amaranth, as a function of the treatments in Puebla, México.

\begin{tabular}{|c|c|c|c|c|c|}
\hline Treatment & $\begin{array}{c}\text { Production } \\
\left(\text { Mean }^{*} \pm \text { S.E. }\right)\left(\mathrm{Kg} \mathrm{ha}^{-1}\right)\end{array}$ & $\begin{array}{c}\text { Loss } \\
\left(\mathrm{Kg} \mathrm{ha}^{-1}\right)\end{array}$ & Loss (\%) & $\begin{array}{l}\text { Value of the loss } \\
\left(\text { USD ha }{ }^{-1}\right)^{\star \star}\end{array}$ & $\begin{array}{c}\text { Cost of the control } \\
\text { per ha (USD) }\end{array}$ \\
\hline Total control & $1003.7 \pm 76.4^{\mathrm{a}}$ & --- & --- & --- & 200.00 \\
\hline Pest control of the foliage & $611.0 \pm 45.1^{\mathrm{b}}$ & 392.7 & 39.1 & 431.97 & 76.40 \\
\hline Pest control of the soil & $560.4 \pm 42.3^{b}$ & 443.3 & 44.2 & 487.63 & 123.60 \\
\hline Without control of pest (control) & $346.6 \pm 25.3^{c}$ & 657.1 & 65.5 & 722.81 & --- \\
\hline
\end{tabular}

*Means with different letters are significantly different (Tukey, DHS $=211.89 \mathrm{Kg}, \mathrm{p}<0.05)$. S.E.: Standard error. ${ }^{* *}$ Determined based on the regional price of the amaranth at harvest in American dollars (November, 2010). 1.1 USD per kg. USD: Dollar of the Unites States of America.

of study. With these results, the number of species recorded as associated with this plant in Puebla, México is notably increased. In a study realized in Guanajuato, México, 43 species were identified in amaranth, but the relationship with the plants was not clear for several species. The 43 species were included only in 17 families of five orders (Salas-Araiza and Borodanenko, 2006).

In contrast to our results, Torres-Saldaña et al. (2004) observed $100 \%$ of plants infected by the borers $H$. truncatulus and $A$. abnormalis in two varieties of $A$. hypocondriacus in Tulyehualco, México, although the number of larvae and percentage of stem tunneling damage did not affect grain yield and biomass production. This work confirms the presence of the insect species previously reported as pests of amaranth (Aragón et al., 1997; Aragón and López-Olguín, 2001) and it is the first record of the occurrence of Trichobaris sp., $P$. ilhuicaminai, and $S$. purpurrascens causing important damage to plants.

This is the first report of quantification of losses for pest insects in the amaranth crop. Considering that the value of the loss is notably higher than the costs of the pest chemical control, it is concluded that the pests of amaranth, both of foliage and of the soil, cause losses of economic importance in the crops of Puebla, México. The development of future researches to establish integrated pest management strategies in this crop are suggested by these results.

\section{Conclusions}

Thirty-four insect species associated with the amaranth crop were determined; of these, the species with the major presence level on the foliage were $S$. exigua and $P$. catullus with 64 and $57 \%$ of infestation, respectively. The borers group caused infestations of $92 \%$, while the white grubs group infests $45 \%$ of the plants. The pests of amaranth as a whole caused a loss of $65.5 \%$ of yield, whereas the pests of foliage and of soil reduce yield by 44.2 and $39.1 \%$, respectively. 


\section{ACKNOWLEDGEMENTS}

The authors express their gratefulness to Miguel Ángel Morón, of the Instituto de Ecología A.C., México, for the identification of the species of Melolonthidae; Nestor Bautista Martínez, of the Colegio de Postgraduados, México, for the identification of the collected material; to the Institution Alternativas y Procesos de Participación Social A.C. for the economic support given in the realization of the work; and to Eugenio Morales, and Avellino Ruiz for the support received during the field work.

\section{REFERENCES}

A Aragón GA, López-Olguín JF (2001). Description and control of the pests the Amaranth. Benemérita Universidad Autónoma de Puebla, Mexico, $p$. 32.

Aragón GA, Tapia-Rojas AM, Huerta-Sánchez SIMT (1997). Insects associated with the Amaranth crop Amaranthus hypocondriacus L.. (Amaranthaceae) in the Tehuacán Valley, Puebla, Mexico. Folia Entomol. Mex., 100: 33-43.

Barba de la Rosa AP, Fomsgaard IS, Laursen B, Mortensen AG, Olvera-Martínez L, Silva-Sánchez C, Mendoza-Herrera A, GonzálezCastañeda J, De León-Rodríguez A (2009). Amaranth (Amaranthus hypochondriacus) as an alternative crop for sustainable food production: Phenolic acids and flavonoids with potential impact on its nutraceutical quality. J. Cereal Sci., 49: 117-121.

Becket R, Meyer D, Wagoner P, Saunders RM (1992). Alternative crops for sustainable agricultural systems. Agric. Ecosyst. Environ., 40: 265-274.

Burton LR, Perkins WD (1989). Rearing the corn earworm and fall armyworm for maize resistance studies. In: CIMMYT (ed) Proceedings of the International Symposium on Methodologies for Developing Host Plant Resistance to Maize Insects, CIMMYT Mexico D.F., pp. 37-45.

Clarke-Harris D, Fleischer SJ (2003). Sequential sampling and biorational chemistries for management of lepidopteran pests of vegetable amaranth in the Caribbean. J. Econ. Entomol., 96: 798804.
Committee on the Common Names of Insects (2011). Common Names of Insects Database. Entomological Society of America, http://www.entsoc.org/common-names, 21.06.2011.

Downton WJS (1973). Amaranthus edulis: a high lysine grain amaranth. World Crops, 25: 20-25.

Espitia RE (1990). Pests and diseases of the Amaranth crop (Amaranthus spp) in Mexico. In: Trinidad, SA, Gomez LF, Suarez RG (Eds) The Amaranth (Amaranthus spp.) its cultivation and use. Colegio de Postgraduados, Mexico, pp. 233-238.

Gimplinger DM, Schulte auf'm Erley G, Dobos G, Kaul H-P (2008). Optimum crop densities for potential yield and harvestable yield of grain amaranth are conflicting. Eur. J. Agron., 28: 119-125.

Gorinstein S, Jaramillo NO, Medina OJ, Rogriques WA, Tosello GA. Paredes-Lopez O (1999). Evaluation of some cereals, plants and tubers through protein Composition. J. Protein Chem., 18: 687-693.

López-Munguía A, Wacher RC, Rolz C, Moser A (1994). Integración de tecnologías indígenas y biotecnologías modernas: una utopía? Interciencia, 19: 177-182.

Mihm JA (1984). Efficient mass-rearing and infestation techniques to screen for host plant resistance to fall armyworm, Spodoptera frugiperda (Smith). CIMMYT, Mexico D.F., Mexico, p. 16.

Salas-Araiza D, Borodanenko A (2006). Insects associated with the Amaranth Amaranthus hypochondriacus L. (Amarantaceae) in Irapuato, Guanajuato, Mexico. Acta Univ., 16: 50-55.

Torres-Saldaña G, Trinidad SA, Reyna TT, Castillo JH, Bautista MN, De León GF (2004). Drilling of the stem of Amaranth by Hypolixus truncatulus (Coleoptera: Curculionidae) and Amauromyza abnormalis (Diptera: Agromyzidae). Acta Zool. Mex. (n.s.), 20: 131-140.

Trinidad SA, Gómez LF, Suárez RG (1990). The Amaranth (Amaranthus spp.) its cultivation and use. Colegio de Postgraduados, Mexico, p. 577. 